\title{
Sensitivity to TRAIL/APO-2L-mediated apoptosis in human renal cell carcinomas and its enhancement by topotecan
}

\author{
M Déjosez ${ }^{1}$, U Ramp ${ }^{1}$, C Mahotka ${ }^{1}$, A Krieg ${ }^{1}$, H Walczak², \\ HE Gabbert ${ }^{1}$ and CD Gerharz ${ }^{*, 1}$ \\ ${ }^{1}$ Institute of Pathology, Heinrich Heine University, D-40225 Duesseldorf, \\ Germany \\ 2 German Cancer Research Center (DKFZ), D-69120 Heidelberg, Germany \\ * Corresponding author: CD Gerharz, Institute of Pathology, Heinrich Heine \\ University, P0 Box 101 007, D-40225 Duesseldorf, Germany. \\ Tel: +49 21181 18348; Fax: +492118118353
}

Received 13.12.99; revised 20.6.00; accepted 12.7.00

Edited by S Nagata

\begin{abstract}
TRAIL (APO-2L) is a newly identified member of the TNF family and induces apoptosis in cancer cells without affecting most non-neoplastic cells, both in vitro and in vivo. Our study focused on the expression and function of TRAIL and its receptors in renal cell carcinoma (RCC) cell lines of all major histological types. Here, we demonstrate that all RCC cell lines express TRAIL as well as the death-inducing receptors TRAILR1 (DR4) and TRAIL-R2 (Killer/DR5). Exposure to TRAIL induced apoptosis in 10 of 16 RCC cell lines. Remarkably, five of six TRAIL-resistant RCC cell lines exhibited high levels of TRAIL expression. Topotecan, a novel topoisomerase I inhibitor, induced upregulation of TRAIL-R2 as well as downregulation of TRAIL. Neutralization of TRAIL with recombinant soluble TRAIL-R1-Fc and TRAIL-R2-Fc failed to inhibit topotecan-induced apoptosis indicating that topotecan-induced cell death can occur in a TRAIL-independent fashion. However, exposure to topotecan resulted in an enhancement of TRAIL-induced apoptosis in all primarily TRAIL-resistant RCC cell lines. This synergistic effect of cotreatment with Topotecan and TRAIL may provide the basis for a new therapeutic approach to induce apoptosis in otherwise unresponsive RCC. Cell Death and Differentiation (2000) 7, 1127-1136.
\end{abstract}

Keywords: TRAIL; apoptosis; topotecan; topoisomerase linhibitor; renal cell carcinoma

Abbreviations: RCC, renal cell carcinoma; $R T$, reverse transcription; TRAIL, TNF-related apoptosis-inducing ligand; HE, hematoxylin-eosin

\section{Introduction}

Metastasic renal cell carcinoma (RCC) is largely resistant to conventional chemotherapy and immunotherapy. ${ }^{1,2}$ This resistance has been explained by various mechanisms, including the multidrug resistance phenotype due to $\mathrm{P}$ glycoprotein over-expression, ${ }^{3}$ different modes of immune evasion, ${ }^{4-6}$ and defects of apoptotic pathways. ${ }^{7}$ Recent evidence indicated that death receptors are directly involved in drug-induced apoptosis. CD95-mediated apoptosis has been implicated in the response of human cancer to cytotoxic drugs and defects of the CD95 signaling cascade were found to contribute to anticancer drug resistance.$^{8-11}$ In addition, one of the genes activated by p53 upon exposure to anticancer drugs is TRAIL-R2, one of the two apoptosisinducing receptors for the tumor necrosis factor (TNF)-related apoptosis-inducing ligand (TRAIL). ${ }^{12,13}$

TRAIL (APO-2L) is a type II transmembrane protein that belongs to the TNF family ${ }^{14,15}$ and selectively induces apoptosis in cancer cells but not in most non-neoplastic cells. $^{16-19}$ In contrast to other apoptosis-inducing TNF family members, such as CD95L, induction of apoptosis through TRAIL appears to be more complex, because four different TRAIL-binding surface-bound receptors have been identified so far. ${ }^{20,21}$ TRAIL-R1 (DR4) and TRAILR2 (DR5/KILLER/TRICK2) are similar in structure, exhibiting a death domain in their cytoplasmatic regions. Overexpression of these receptors was shown to induce apoptotic cell death. ${ }^{16,18,22,23}$ Besides these apoptosisinducing TRAIL receptors, two additional non-apoptosisinducing TRAIL receptors, TRAIL-R3 (DcR1/TRID) ${ }^{16,23-26}$ and TRAIL-R4 (DcR2/TRUNDD), ${ }^{27-29}$ have been identified. Both non-apoptosis-inducing receptors harbor an extracellular TRAIL-binding region but lack a functional cytoplasmatic death domain: TRAIL-R3 does not contain an intracellular signaling domain, whereas TRAIL-R4 exhibits a truncated death domain. Overexpression of these receptors after transfection did not trigger cell death but rather protected mammalian cells from TRAIL-induced apoptosis. ${ }^{23,27,29}$ These data led to the suggestion that TRAIL-R3 and TRAIL-R4 may serve as apoptosisinhibitory 'decoy' receptors for TRAIL. However, thus far, this hypothesis has not been verified in any cell type under non-overexpression conditions. ${ }^{30}$ TRAIL and its receptors TRAIL-R1, -R2 and -R4 have been detected in a wide array of both non-neoplastic and neoplastic cells. $^{12,14-16,18,22,23,27-29}$ In contrast, the expression of TRAIL-R3 was found to be more restricted. However, the exact distribution of TRAIL-R3 mRNA remains controversial as it was detected either in peripheral blood mononuclear cells only ${ }^{24}$ or in a wider range of nonneoplastic cells. ${ }^{16,23}$ The precise physiological and pathological roles of TRAIL-mediated apoptosis are not well characterized so far and remain to be further elucidated. Recent observations, however, suggested that TRAIL constitutes an additional pathway of T-cell cytotoxicity directed against virus-infected cells and various tumor cells including human RCCs. ${ }^{31}$

Although TRAIL had been reported to induce apoptosis in many different cancer cells without affecting most nonneoplastic cells in vitro, it remained unclear whether this 
selective apoptosis-inducing effect would be maintained in vivo. However, it was shown recently, that TRAIL exhibits potent anti-tumor activity upon systemic administration in vivo without any of the deleterious side effects on normal tissues known from TNF- $\alpha$ or CD95L. ${ }^{19,32}$ Ashkenazi et $a l^{19}$ also observed responsiveness to TRAIL/APO-2Lmediated apoptosis in some RCC cell lines. These observations raise the possibility that TRAIL/APO-2L, either alone or in combination with other strategies, might become a powerful cancer therapeutic for otherwise unresponsive RCCs.

Therefore, we investigated the expression and function of TRAIL and its corresponding receptors in a large panel of RCC cell lines of all major histological types. In addition, we used the topoisomerase I inhibitor topotecan (Hycamtin ${ }^{\mathbb{B}}$ ), which is only a weak substrate for P-glycoprotein, ${ }^{33}$ to evaluate the role of the TRAIL system for anticancer drug-induced apoptosis in human RCCs.

\section{Results}

\section{Expression of TRAIL and its corresponding receptors in human RCCs}

To get insight into the role of the TRAIL system in human RCCs of different histological types, we first analyzed the expression of TRAIL and its different receptors in 16 RCC cell lines using RT - PCR analysis and RNase protection assays. TRAIL expression was found in all RCC cell lines by RTPCR (data not shown). In RNase protection assays, however, the extent of TRAIL expression markedly varied between the various RCC cell lines from weak to intensive signals (Figure $1 \mathrm{~A})$ and could be detected in some cell lines only after prolonged autoradiography (data not shown).

TRAIL-R1 mRNA was found in all RCC cell lines with the exception of chrompho-A, which was derived from a rare $\mathrm{RCC}$ variant, the chromophobe type of RCC (Figure 1A). ClearCa-5 cells exhibited TRAIL-R1 mRNA by RT-PCR analysis and by RNase protection assays after prolonged autoradiography (data not shown). TRAIL-R2 transcripts were found in all RCC cell lines and their expression levels uniformly exceeded those of TRAIL-R1 (Figure 1A). As shown in Figure 1B, two different specific amplification products (120 and $217 \mathrm{bp}$ ) of TRAIL-R2 were detected by RT-PCR and verified as TRICK2A and TRICK2B ${ }^{34,35}$ by sequence analysis (data not shown). TRAIL-R3 was found in some RCC cell lines by RT-PCR only (Figure 1B), while it was not detectable by RNase protection assay. In contrast, TRAIL-R4 was detected in all RCC cell lines with the exception of chrompho-A. The expression levels, however, were rather low (Figure 1A) and signals could be detected in some RCC cell lines after prolonged autoradiography only (data not shown).

\section{TRAIL-mediated apoptosis in human RCCs}

To evaluate the functionality of the TRAIL-signaling pathway and the extent of TRAIL-mediated apoptosis, we used recombinant human soluble (rhs) TRAIL, thereby confronting our RCC cell lines with a uniform apoptotic signal. (rhs TRAIL
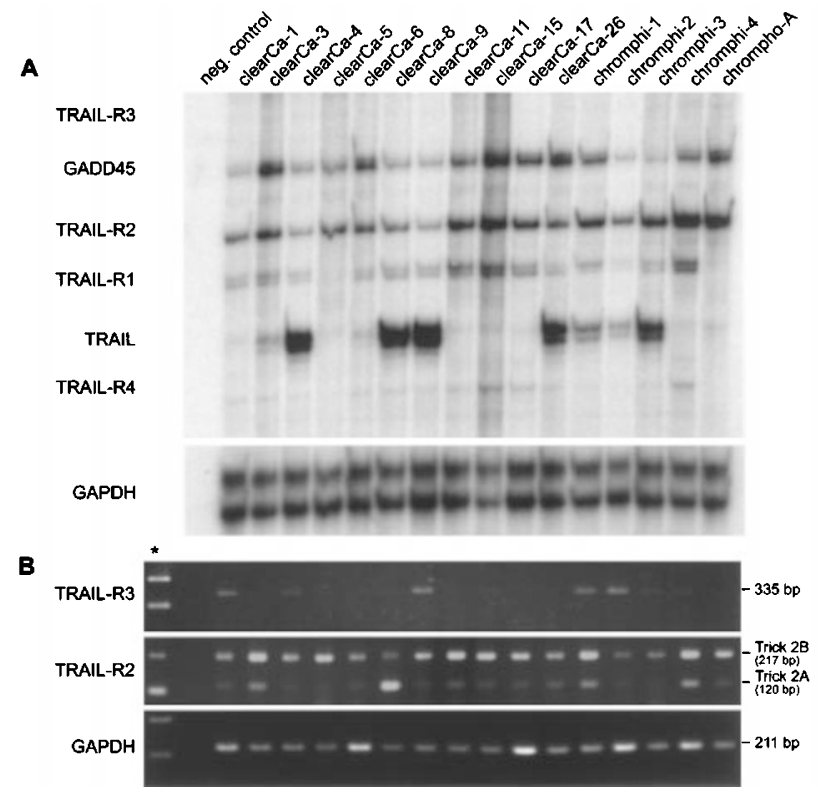

Figure 1 Expression of TRAIL and its receptors in 16 human RCC cell lines of different histological types. (A) $20 \mu \mathrm{g}$ of total RNA were analyzed by RNase protection assay for expression of TRAIL, TRAIL-R1, -R2, -R3 and -R4. GAPDH served as control for equal RNA concentrations. (B) Two $\mu \mathrm{g}$ of total RNA was used in RT-PCR analysis for detecting TRAIL-R3 (upper panel) and TRAIL-R2 (lower panel). TRICK2A and TRICK2B are alternative splicing variants of TRAIL-R2. GAPDH detection was used as control for integrity of RNA and RT-PCR reactions. ${ }^{*} 100$ bp ladder

is a soluble form of TRAIL tagged with a FLAG-epitope and its activity is enhanced by simultaneous incubation with a FLAGantibody as described in Materials and Methods). In standard growth medium, tumor cells undergoing apoptosis were observed in all RCC cell lines, albeit with low frequencies ranging from 0.2 to $3.9 \%$. After exposure to TRAIL (100 ng/ml) for $48 \mathrm{~h}$, a markedly heterogeneous response was observed. A pronounced decrease of cell viability ( $<80 \%$ of the control) became evident in 10 out of 16 RCC cell lines (Figure 2) with reduction of cell viability to $10 \pm 1 \%$ of the control in the most responsive cell line. In six cell lines we did not observe a reduction of cell number or only a modest response of doubtful biological significance (Figure 2).

The response to exogenous TRAIL could not be related to the expression levels of TRAIL receptors. However, five out of six cell lines that had been resistant to TRAILinduced apoptosis (clearCa-4, -8, -9, -26 and chromphi-3) revealed the highest levels of TRAIL mRNA expression. This observation might indicate a process selecting for TRAIL resistance in RCC cells with high levels of TRAIL expression, thereby precluding fratricide of neighboring tumor cells.

Of note, five out of six RCC cell lines, which had been resistant to TRAIL-mediated apoptosis also proved to be resistant to CD95-mediated apoptosis, as indicated by the failure to induce apoptosis by the agonistic anti-CD95 antibody $\mathrm{CH} 11$ (Figure 2). Similar observations have previously been reported by Griffith et al. ${ }^{36}$ and Thomas and Hersey ${ }^{37}$ using melanoma cells. 


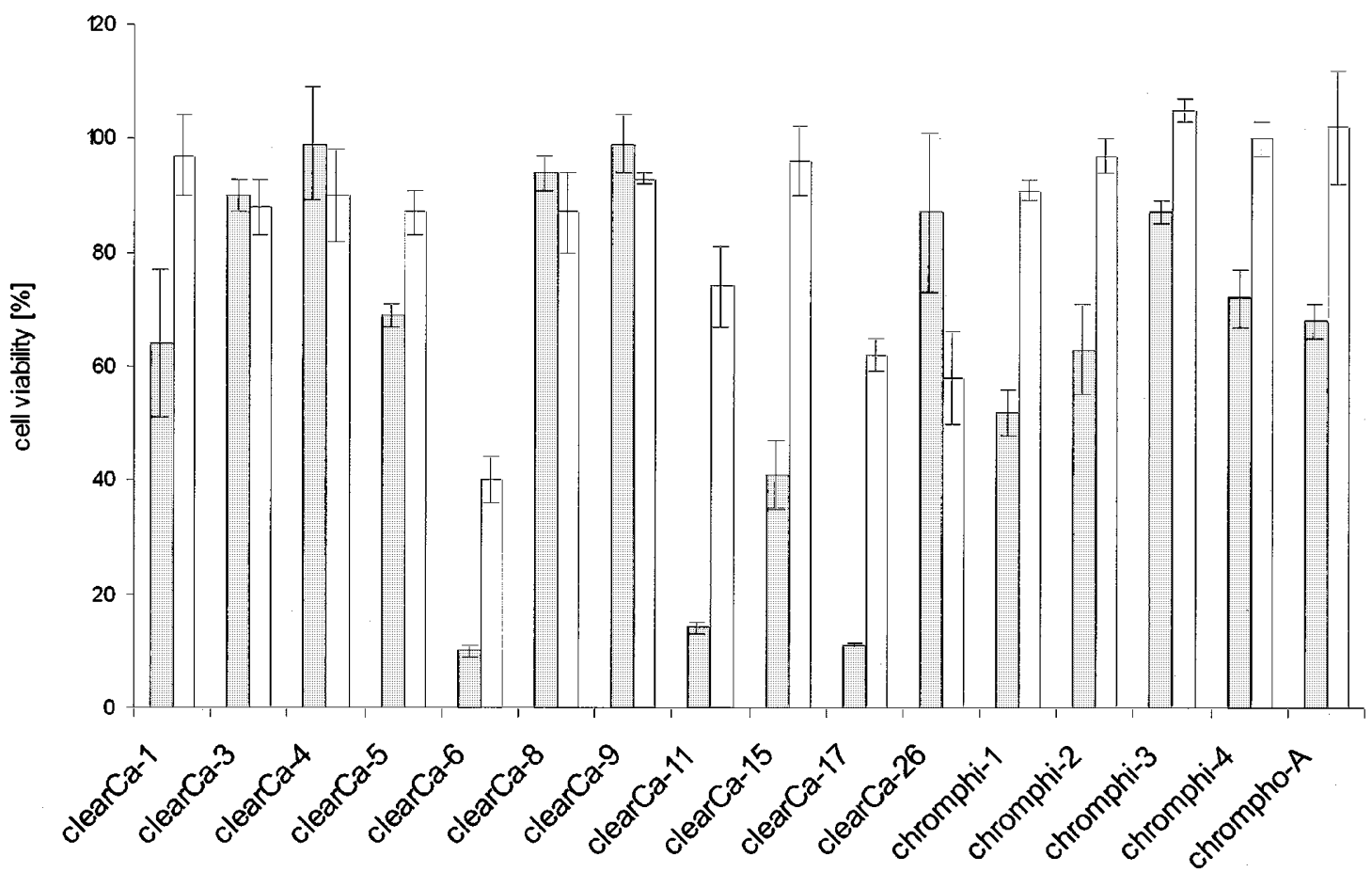

Figure 2 Sensitivity of human RCC cell lines to TRAIL- and CH11-induced cell death. Cells were cultured for $48 \mathrm{~h}$ in the presence of $100 \mathrm{ng} / \mathrm{ml} \mathrm{TRAIL} \mathrm{(gray} \mathrm{bars)}$ or $500 \mathrm{ng} / \mathrm{ml} \mathrm{CH} 11$ (white bars). Cell proliferation was measured by MTT assay

\section{Topotecan-induced apoptosis and upregulation of TRAIL receptors in RCCs}

To assess the role of the TRAIL system in anticancer druginduced apoptosis of RCCs, four RCC cell lines (clearCa-6, $15,-17$, chromphi-3) were exposed to topotecan $\left(\right.$ Hycamtin $^{\mathbb{R}}$ ), a novel topoisomerase I inhibitor with weak substrate affinity to P-glycoprotein. ${ }^{33,38}$ Light microscopic evaluation revealed a dose-dependent increase of specific apoptotic death in three out of four cell lines (Figure 3). This induction of apoptosis was paralleled by a significant dose-dependent reduction of cell number with $\mathrm{IC}_{50}$ values between $0.3 \mu \mathrm{g} / \mathrm{ml}$ to $2.3 \mu \mathrm{g} / \mathrm{ml}$ (Figure 3). After exposure to topotecan, RNase protection assays demonstrated downregulation of TRAIL in two RCC cell lines (clearCa-17 and chromphi-3) which had shown high basic levels of TRAIL expression (Figure 4). In contrast, TRAIL-R1 and TRAIL-R2 mRNA expression increased in all those cell lines which had shown pronounced topotecan-induced apoptosis (i.e. clearCa-6, -17, and chromphi-3) (Figure 4). Flow cytometric analysis, however, revealed topotecan-induced upregulation of only TRAIL-R2 in clearCa-6 and chromphi-3, whereas TRAIL-R1 and TRAIL-R2 were not upregulated on the surface of the other two cell lines tested (Figure 5).

Interestingly, a weak upregulation of mRNA expression was also observed for TRAIL-R4 in those cell lines which had responded with induction of apoptosis upon topotecan treatment (Figure 4). TRAIL-R3 was not detectable by RNase protection assay even after prolonged topotecan treatment for $72 \mathrm{~h}$.

\section{Topotecan-induced upregulation of TRAIL-R2 despite p53 mutation}

Because the expression of TRAIL-R2 had been observed to be upregulated by p53 after exposure to anticancer agents, ${ }^{12,13}$ we additionally defined the mutational status of p53 in our RCC cell lines. Sequencing of p53 exons 5-8, which are the most commonly affected hot spot regions for p53 mutations in human cancer, ${ }^{39,40}$ revealed to mutations in clearCa-15 and chromphi-3. In contrast, isolated point mutations were found in clearCa- 6 and -17 (Table 1). Nevertheless, clearCa- 6 and -17 responded with upregulation of TRAIL-R2 mRNA upon exposure to topotecan. These cell lines were also still able to transcriptionally activate GADD45 (Figure 4), known to be directly regulated by p53. ${ }^{41}$ These data indicate that the p53 mutations observed in the RCC cell lines tested might not be functionally relevant for regulation of TRAIL-R2.

\section{Topotecan-induced apoptosis is not mediated via the TRAIL pathway in human RCCs}

The upregulation of TRAIL-R2 protein expression in clearCa- 6 and chromphi-3 might contribute to topotecan-induced apoptosis via receptor activation by tumor cell-derived TRAIL. To test this hypothesis, we tried to block topotecaninduced apoptosis by neutralizing TRAIL ligands, using the recombinant human TRAIL-R1-Fc and TRAIL-R2-Fc chimeric receptors. (These chimeric receptors are fusion proteins of the extracellular regions of TRAIL-R1 (aa 1-239) and TRAIL- 

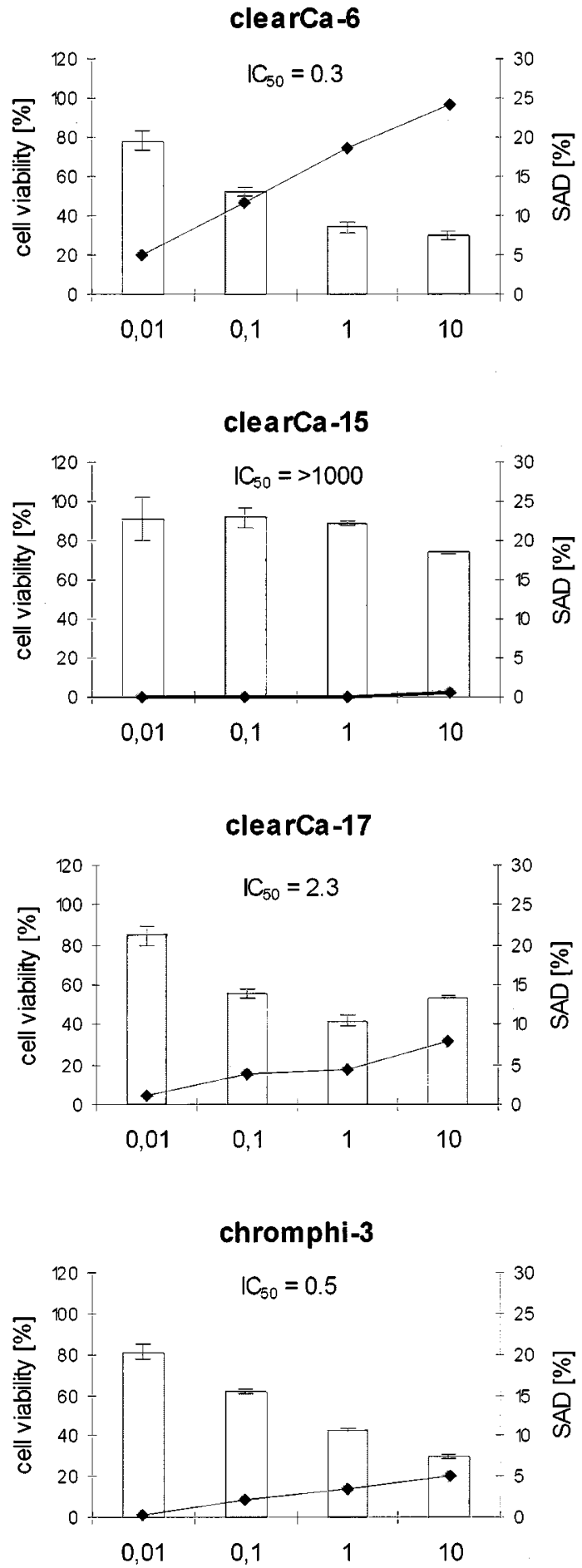

Figure 3 Topotecan-induced cell death in human RCC cell lines. Four RCC cell lines (clearCa-6, -15, -17 and chromphi-3) were cultured in the presence of the indicated concentrations of topotecan for $48 \mathrm{~h}$. Cell viability was measured by MTT assay (bars) and specific apoptotic death (SAD) was determined by light microscopic counting after HE-staining

R2 (aa 1-182) with a carboxyterminal histidine-tagged FC portion of human $\operatorname{lgG} 1 .^{18,22,42}$ If the apoptotic effects of topotecan were actually mediated via the TRAIL system, simultaneous incubation with these soluble chimeric receptors should block the effects of topotecan.

In these experiments, the reduction of cell number observed after exposure to topotecan as a single agent could not be inhibited by simultaneous exposure to the chimeric recombinant soluble TRAIL receptors in any cell line (Figure 6). This observation strongly argued against an involvement of TRAIL receptor activation by TRAIL binding in topotecan-induced apoptosis.

\section{Topotecan synergistically enhances susceptibility for TRAIL-mediated apoptosis in primarily TRAIL-resistant RCCs}

Topotecan-mediated upregulation of TRAIL-R2 in clearCa-6 and chromphi-3 obviously was not sufficient for an effective paracrine activation of the TRAIL system via tumor cellderived TRAIL. Nevertheless, topotecan-induced upregulation of TRAIL-R2 might sensitize for TRAIL-mediated apoptosis. To test this hypothesis, TRAIL-resistant RCC cell lines were simultaneously exposed to both topotecan $(1 \mu \mathrm{g} /$ $\mathrm{ml}$ ) and TRAIL (100 ng/ml) for $48 \mathrm{~h}$. As shown in Figure 7, all primarily TRAIL-resistant RCC cell lines responded with a striking reduction in cell viability. Fractional inhibition analysis revealed that the effects of TRAIL and topotecan in combination were synergistic compared with either agent alone.

\section{Discussion}

TRAIL has recently been shown to induce apoptosis of tumor cells in vivo without deleterious side effects on normal tissues. ${ }^{19,32}$ Because cancer therapy most potently operates through induction of apoptosis, this newly recognized apoptosis-inducing receptor-ligand system could provide powerful therapeutic options for the treatment of human RCCs.

The data presented here demonstrate TRAIL expression in human RCCs of all major histological types. Moreover, RCCs exhibited expression of TRAIL-R1 as well as TRAILR2, but only low mRNA expression levels of TRAIL-R4. In contrast, TRAIL-R3 could be detected by RT-PCR analysis in some RCCs yet, by RNase protection assay, it was not detectable in any of the RCCs tested. This observation is consistent with previous studies which demonstrated TRAIL-R3 mRNA expression in non-neoplastic tissues, but not in most cancer cell lines examined so far. $^{16,24,43}$

Despite the constitutive coexpression of TRAIL and its apoptosis-inducing receptors TRAIL-R1 and -R2, spontaneous apoptosis was quite infrequent in our RCC cell lines. These observations suggested some degree of resistance to TRAIL-mediated apoptosis in RCCs. Nevertheless, the essential components of the machinery involved in the execution of TRAIL-triggered cell death were present in most RCC cell lines, as TRAIL was capable of inducing apoptosis in 10 out of $16(63 \%)$ RCC cell lines, irrespective of their histological types. Similar observations on TRAIL sensitivity have recently been reported by Kayagaki et a/ and Ashkenazi et $a l^{19}$ for a small number of RCC cell lines, 
clearCa-6

$\begin{array}{lllllll}0 & 1 & 6 & 12 & 24 & 48 & 72\end{array}$

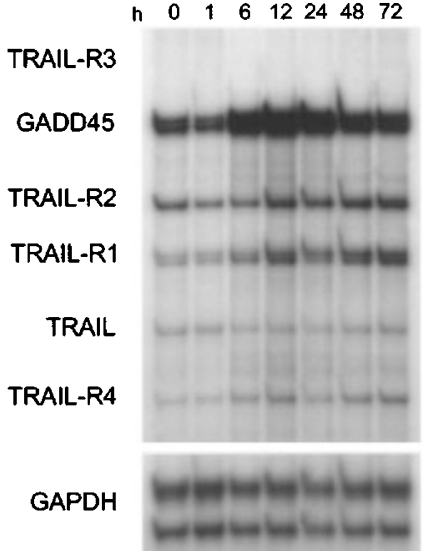

clearCa-15

$\begin{array}{llllllll}0 & 1 & 6 & 12 & 24 & 48 & 72\end{array}$

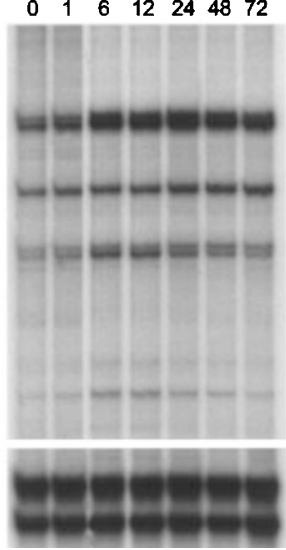

clearCa-17

$\begin{array}{lllllll}0 & 1 & 6 & 12 & 24 & 48 & 72\end{array}$

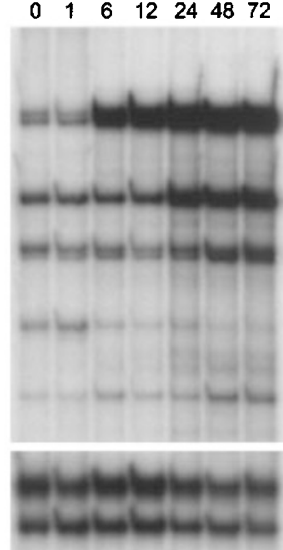

\section{chromphi-3}

$\begin{array}{llllllll}0 & 1 & 6 & 12 & 24 & 48 & 72\end{array}$

Figure 4 Expression of TRAIL and its receptors in human RCC cell lines after topotecan treatment. Cells were cultured for the indicated time period in the presence of topotecan $(1 \mu \mathrm{g} / \mathrm{ml})$. Total RNA was extracted and $20 \mu \mathrm{g}$ were analyzed by RNase protection assay. GAPDH signal served as control for equal RNA concentrations

clear Ca-6
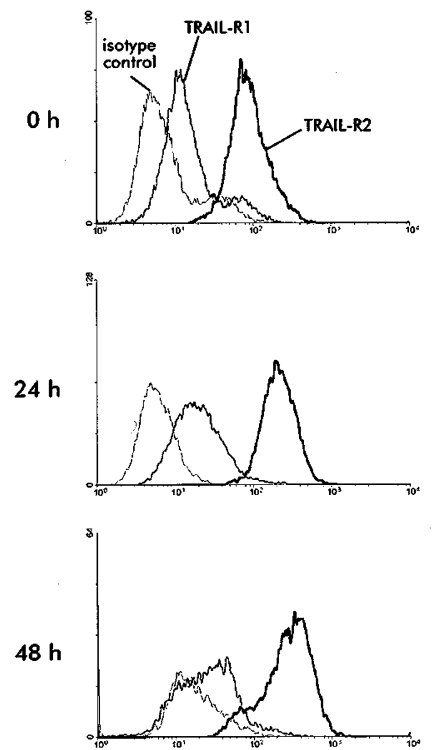

clearCa-15
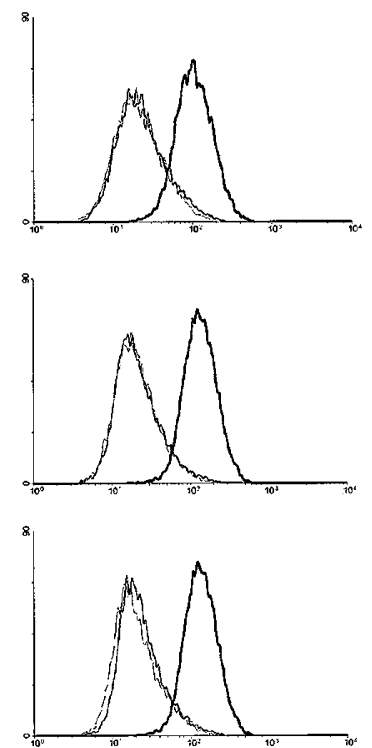

clearCa-17
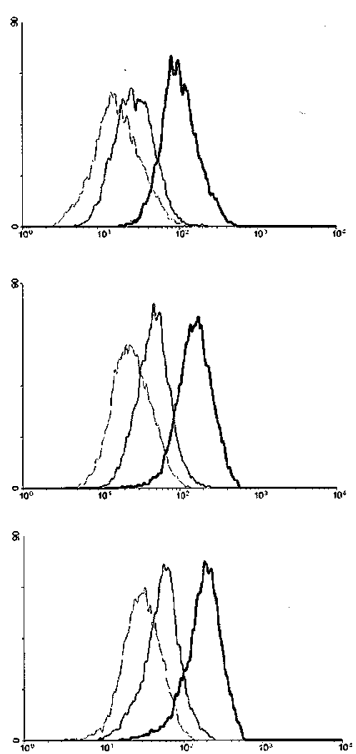

chromphi-3
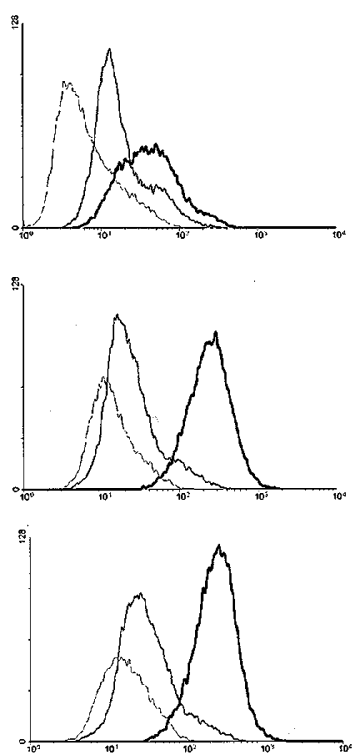

Figure 5 Surface expression of TRAIL-R1 and TRAIL-R2 before and after topotecan treatment. $1 \times 10^{5}$ cells were analyzed by flow cytometry with antibodies specific for TRAIL-R1 and TRAIL-R2. Analysis was performed before $(0 \mathrm{~h})$ and after treatment with $1 \mu \mathrm{g} / \mathrm{ml}$ topotecan for 24 and $48 \mathrm{~h}$

Table 1 p53 mutational status of clearCa-6, -15, -17 and chromphi-3

\begin{tabular}{lc}
\hline Cell line & p53 status \\
\hline clearCa-6 & $\operatorname{Arg}^{290} \rightarrow$ His \\
clearCa-15 & wt \\
clearCa-17 & $\operatorname{Arg}^{213} \rightarrow$ Leu \\
chromphi-3 & wt \\
\hline
\end{tabular}

Two of four RCC cell lines showed substitution of Arg at position 213 and 290 to Leu or His. wt=wildtype

although the proportion of non-responders was larger in our panel of RCC cell lines. The extent of response in our RCC cell lines closely corresponded to that described in hematological malignancies ${ }^{44}$ and tended to exceed that reported for breast cancer cell lines. ${ }^{45}$ The demonstration of TRAIL-mediated apoptosis in human RCCs was important, because it proved the existence of a potent mechanism of self-destruction in most human RCCs, provided that appropriate stimuli can be applied or sensitivity to weak stimuli can be raised.

Thus far, little is known about the mechanisms that confer responsiveness or resistance to TRAIL-mediated apoptosis in human RCCs. The propagation of TRAILmediated cell death, however, is regulated at different levels along the TRAIL-dependent signal transduction 

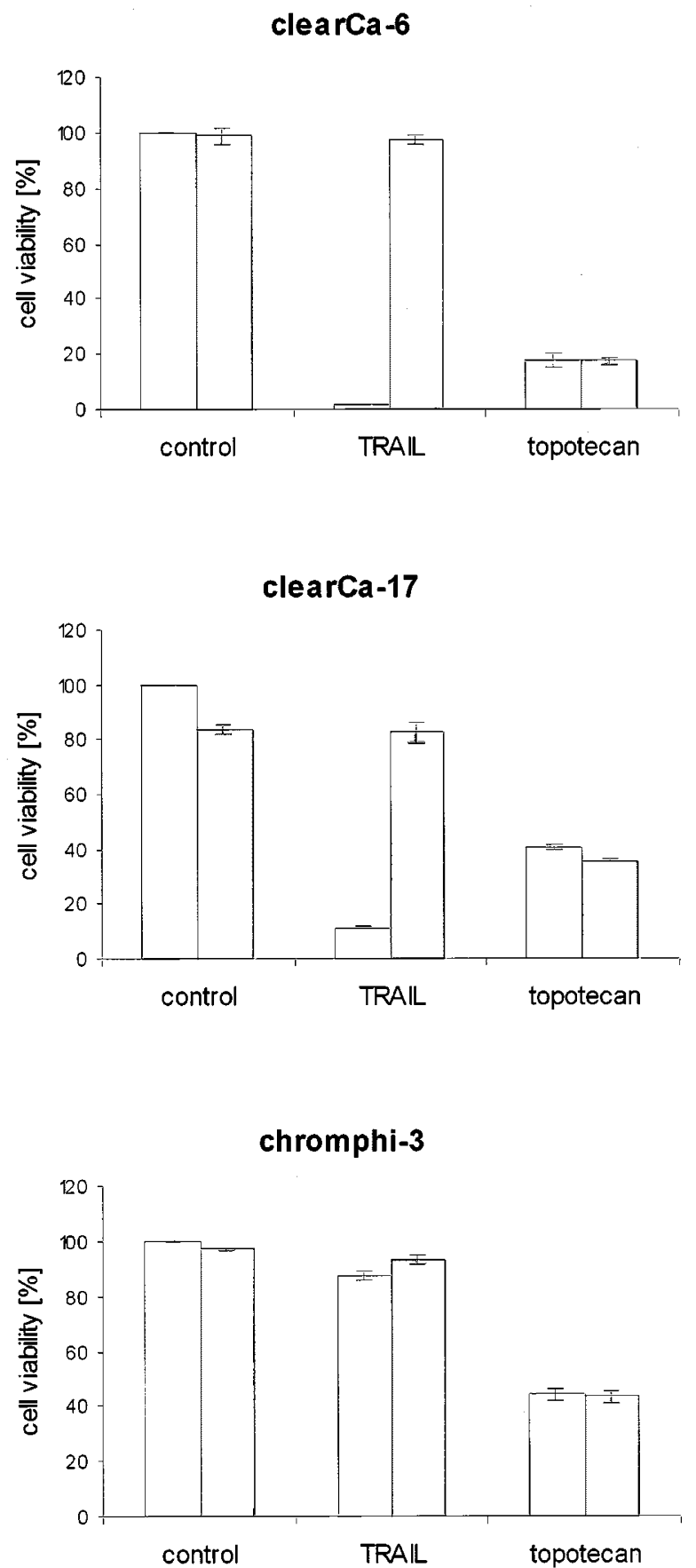

Figure 6 Topotecan-induced apoptosis in human RCCs is independent of the TRAIL system. The topotecan-sensitive cell lines clearCa-6, -17 and chromphi-3 were cultured for $48 \mathrm{~h}$ without (white bars) or with (gray bars) recombinant human TRAIL-R1-Fc and TRAIL-R2-Fc in standard growth medium ('control') or in presence of $100 \mathrm{ng} / \mathrm{ml}$ TRAIL ('TRAIL') or $1 \mu \mathrm{g} / \mathrm{ml}$ topotecan ('topotecan'). Cell viability was measured by MTT assay

cascade. The function of the TRAIL system does not only depend on the effective interaction between TRAIL and its death-inducing receptors TRAIL-R1 and TRAIL-R2, but is additionally determined by the balance of other pro- and anti-apoptotic regulator proteins. These may include-inter

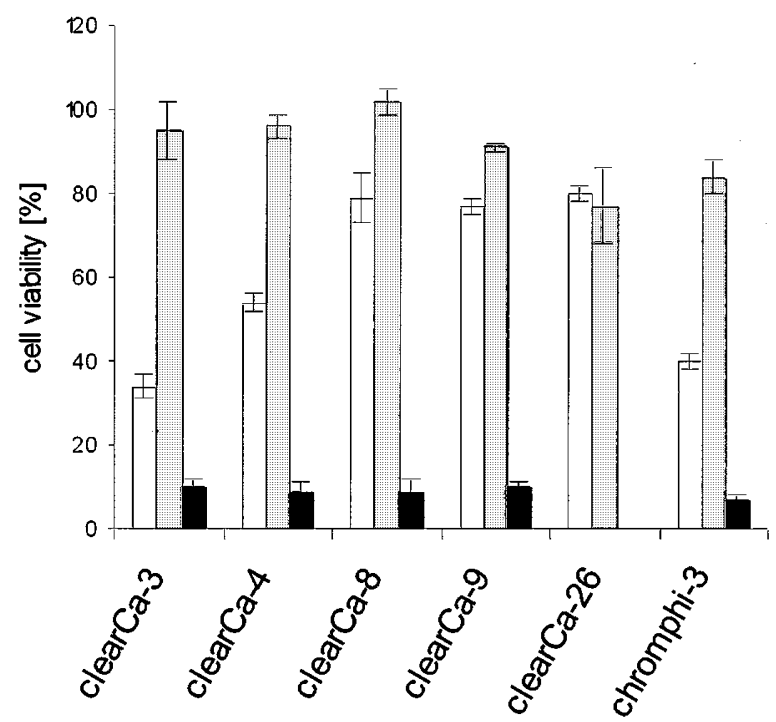

Figure 7 Synergistic enhancement of TRAIL-induced apoptosis in human RCCs by topotecan. Primarily TRAIL-resistant RCC cell lines were cultured for $48 \mathrm{~h}$ in the presence of $1 \mu \mathrm{g} / \mathrm{ml}$ topotecan (white bars), $100 \mathrm{ng} / \mathrm{ml}$ TRAIL (gray bars) alone or combined (dark gray bars). Cell viability was determined by MTT assays

alia-osteoprotegerin (OPG), FLICE-inhibitory proteins (FLIPs) as well as members of the $\mathrm{Bcl}-2$ and IAP (inhibitor of apoptosis protein) families. ${ }^{30,46}$ Therefore, it was not surprising that the extent of TRAIL-induced apoptosis observed in our RCC cell lines could not be correlated to the expression levels of the apoptosis-inducing receptors TRAIL-R1 and TRAIL-R2.

Of note, five out of six RCC cell lines with remarkably high levels of TRAIL transcripts proved to be resistant to apoptosis triggered by TRAIL. This observation might indicate a process selecting for TRAIL resistance in RCC cell lines with high levels of TRAIL expression, thereby precluding fratricide between neighboring tumor cells. Although we cannot exclude that this selective process took place during in vitro cultivation of our RCC cell lines, RCC cells might have benefited from this selective process already under in vivo conditions. In close analogy to the CD95 system, ${ }^{47,48}$ high levels of TRAIL and simultaneous resistance to TRAIL-mediated apoptosis could facilitate immune evasion of RCC cells in vivo. These RCC cells could ward off the attack of TRAlL-bearing immunocompetent cells. ${ }^{31}$ Thus, the observed correlation between high levels of TRAIL expression and resistance to TRAILinduced apoptosis may prove to be clinically relevant. Thereby, the level of TRAIL expression in human RCCs might provide a prognostic indicator for the responsiveness to TRAIL treatment.

Only recently, CD95-triggered apoptosis has been identified as a key mediator of chemotherapy in various leukemias and some solid tumor types. Anticancer drugs were shown to induce upregulation of CD95 receptor and ligand, the interaction of which resulted in fratricide between neighboring tumor cells. ${ }^{8,10,11}$ Vice versa, resistance to anticancer drugs has been shown to be associated 
with defects of the CD95 system. ${ }^{9}$ Therefore, we asked whether the TRAIL system might also be directly involved in anticancer drug-induced apoptosis of human RCCs. Interestingly in this context, TRAIL-R2 had been identified by subtractive hybridization screening of a library obtained from teratocarcinoma cells after treatment with anticancer drugs. $^{12,13}$

Our data demonstrate that therapeutically relevant concentrations of topotecan ${ }^{38}$ induced a marked dosedependent increase of apoptosis and a significant reduction of cell number in three out of four RCC cell lines. The response to topotecan was paralleled by an increase in the surface expression of TRAIL-R2 in two out of three topotecan-responsive RCC cell lines. This observation suggested that the TRAIL system might actually be involved in chemotherapy-induced apoptosis, as had previously been demonstrated for the CD95 system. $^{9,11}$ To further test this hypothesis, we utilized recombinant human TRAIL-R1-Fc and TRAIL-R2-FC proteins. These agents competitively block the binding of TRAIL to its receptors, thereby preventing signal transduction via the TRAIL system. However, both TRAIL-R1-Fc and TRAIL-R2-Fc failed to inhibit topotecan-induced apoptosis. These data indicate that the cytotoxicity of topotecan can occur via TRAIL-independent mechanisms in human RCCs.

As demonstrated in our study, topotecan-induced upregulation of TRAIL-R2 did not result in effective fratricide via paracrine activation of the TRAIL system between neighboring RCC tumor cells. Nevertheless, this upregulation of TRAIL-R2 might be exploited for tumor treatment by administration of exogenous TRAIL in combination with topotecan. In fact, all primarily TRAILresistant RCC cell lines of our study responded with a striking reduction in cell viability when exposed to both topotecan and exogenous TRAIL. Fractional inhibition analysis revealed that the effect observed upon combination of TRAIL and topotecan was synergistic compared with either agent alone. Similar observations have recently been reported for breast carcinoma cell lines ${ }^{44}$ and colon carcinoma transplants in SCID mice ${ }^{49}$ after combined exposure to doxorubicin and TRAIL ${ }^{44}$ or CPT-11 and TRAIL, ${ }^{49}$ respectively. However, doxorubicin did not affect the expression of any TRAIL receptor in these breast carcinoma cell lines. Thus, the mechanisms underlying the synergism between chemotherapeutic drugs and TRAIL in terms of apoptosis induction in tumor cells appear to vary between different tumors and anticancer drugs.

In summary, our data demonstrate a marked heterogeneity in the responsiveness of human RCC cell lines to TRAIL-mediated cell death. Importantly, although topotecan-induced cytotoxicity can occur independent of the TRAIL system, this anticancer drug synergistically enhanced susceptibility to TRAIL-mediated apoptosis in primarily TRAIL-resistant human RCCs. The synergistic effect described here suggests that activation of the TRAIL pathway, either alone or in combination with topotecan or similar chemotherapeutic drugs, may become an attractive therapeutic strategy in different types of human RCC.

\section{Materials and Methods}

\section{Cell lines and cell culture}

All cell lines used in this study were derived from typical representatives of the clear cell, chromophilic/papillary, and chromophobe types of RCC, established in our laboratory as previously described. ${ }^{50-53}$ The cell lines were maintained with Dulbecco's modified Eagle's medium (DMEM, Gibco, Germany) supplemented with $10 \%$ fetal calf serum (FCS), $100 \mathrm{U} / \mathrm{ml}$ penicillin as well as $100 \mu \mathrm{g} / \mathrm{ml}$ streptomycin and cultivated at $37^{\circ} \mathrm{C}$ in an atmosphere with $5 \% \mathrm{CO}_{2}$.

\section{RNA purification from cultured cells}

Total cellular RNA was isolated from RCC cell lines using either the RNeasy kit (Qiagen, Germany) for RT-PCR analysis, or the cesium chloride ultracentrifugation method ${ }^{54}$ for RNase protection assays. RNA concentration was measured by photometry at $260 \mathrm{~nm}$. The quality of total cellular RNA was verified by the integrity of $18 \mathrm{~S} / 28 \mathrm{~S}$ ribosomal RNA in ethidium bromide-stained agarose gels.

\section{RNase protection assays}

Cells $\left(3 \times 10^{6}\right.$ to $\left.10 \times 10^{6}\right)$ were treated with $1 \mu \mathrm{g} / \mathrm{ml}$ topotecan for 1,6 , $12,24,48$ or $72 \mathrm{~h}$ and RNA was subsequently isolated. Twenty $\mu \mathrm{g}$ of total RNA were analyzed for the presence of TRAIL, TRAIL-R1, -R2, -R3 and -R4 as well as GADD45 transcripts by RNase protection assays. These were performed with the RiboQuant Multi-Probe RNase protection assay system (Pharmingen, USA) according to the manufacturer's recommendations using the RiboQuant custom template set \#559129. GAPDH was included as internal control. The protected probes were separated on $6 \%$ denaturing polyacrylamide gels and visualized by autoradiography.

\section{RT - PCR analysis}

For monitoring TRAIL-R2 and TRAIL-R3 on mRNA level, reverse transcription was performed using $2 \mu \mathrm{g}$ of total cellular RNA, $25 \mathrm{nmol}$ dNTPs (Stratagene, USA), $20 \mathrm{U}$ of Recombinant RNasin Ribonuclease Inhibitor (Promega, Germany), 100 pmol random primer (in the case of TRAIL-R2; Stratagene, USA) or $10 \mathrm{pmol}$ of the gene-specific $3^{\prime}$-primer (in the case of TRAIL-R3) as well as $5 \mathrm{U}$ AMV reverse transcriptase (Promega, USA) with the corresponding RT-buffer in a final volume of $30 \mu \mathrm{l}$. The reactions were incubated at $55^{\circ} \mathrm{C}$ for $1 \mathrm{~h}$.

The PCR mixture for TRAIL-R2 and GAPDH was composed as follows: $1.5 \mu$ of the cDNA template, $25 \mathrm{pmol}$ of each gene-specific primer, $12.5 \mathrm{nmol}$ dNTPs (Stratagene, USA) and $1.5 \mathrm{U} \mathrm{Taq}$ polymerase (Sigma, Germany) with the corresponding buffer in a final volume of $50 \mu \mathrm{l}$. The mixture for amplification of TRAIL-R3 was similar but $2.5 \mathrm{U}$ AmpliTaq Gold and the recommended buffer supplemented with $1.2 \mathrm{mM} \mathrm{MgCl}_{2}$ (Perkin Elmer, USA) were applied. The following primer sequences were used: TRAIL-R2forward: $5^{\prime}>$ GGGAAGAAGATTCTCCTGAGATGTG $<3$ '; TRAIL-R2reverse: 5'>ACATTGTCCTCAGCCCCAGGTCG $<3^{\prime 85}$; TRAIL-R3forward: 5'>CTGCCAGTCC TAGCTTACTCTG $<3^{\prime}$; TRAIL-R3-reverse: 5'>CTGCTACACTTCC GGCACATCT < 3'; GAPDH-forward: 5'> ACGGATTTGGTCGTATTGGGCG < 3'; GAPD H-reverse: 5'> CTCCTGGAAGATGGTGATGG $<3$ '.

The initial denaturation step at $94^{\circ} \mathrm{C}$ for 2 min was followed by 35 cycles (or 27 cycles for GAPDH) of denaturation for $30 \mathrm{~s}$ (GAPDH) or $1 \mathrm{~min}$ (TRAIL-R2, -R3), annealing for $1 \mathrm{~min}$ at $64^{\circ} \mathrm{C}$ (GAPDH) or $55^{\circ} \mathrm{C}$ (TRAIL-R2, -R3), extension at $72^{\circ} \mathrm{C}$ for $1 \mathrm{~min}$ and a final extension 
step at $72^{\circ} \mathrm{C}$ for 5 min. PCR products were separated on $3 \%$ agarose gels and the identity of the amplification products was confirmed by direct sequencing.

\section{Flow cytometric analysis}

The expression of TRAIL-R1 and TRAIL-R2 was assessed by fluorescence-activated cytometry in a FACScan flow cytometer (Becton-Dickinson, Germany), using the CellQest software system. After culturing RCC cells for 24 and $48 \mathrm{~h}$ in the absence or presence of $1 \mu \mathrm{g} / \mathrm{ml}$ topotecan, the cells were harvested by incubation for $5 \mathrm{~min}$ with $0.05 \%(\mathrm{w} / \mathrm{v})$ EDTA in PBS. A total of $1 \times 10^{5}$ cells was transferred into polystyrene tubes, placed on ice, and washed twice with washing buffer (3\% FCS in PBS). Afterwards, the cells were incubated for $30 \mathrm{~min}$ at $4^{\circ} \mathrm{C}$ with $1 \mu \mathrm{g} / \mathrm{ml}$ of the primary antibodies TRAIL-R1 (clone M272), TRAIL-R2 (clone M413) or mouse-lgG $1,2.5 \mu \mathrm{g} / \mathrm{ml}$ of the secondary biotinylated-goat anti-mouse antibody and $2.5 \mu \mathrm{g} / \mathrm{ml} \mathrm{PE-}$ labeled streptavidine. Between each incubation step the cells were washed twice with washing buffer and after the last washing procedure, the cells were measured. TRAIL-R1- and TRAIL-R2specific monoclonal antibodies were kindly provided by Immunex Corp. (Seattle, WA, USA). Isotype-matched mouse-IgG1, biotinylated goat anti-mouse $\lg \mathrm{G}$ as well as PE-labeled streptavidine were obtained from PharMingen (Germany).

\section{Sequence analysis of RT-PCR products}

Bands of interest were eluted from agarose gels using the QIA quick gel extraction kit (Qiagen, Germany), ligated into the pGEM-T-cloning vector (Promega, Germany) and cloned in accordance with standard protocols. Plasmid DNA was recovered employing the Plasmid Mini Kit (Qiagen, Germany) and analyzed with an ABI Prism 310 sequencing apparatus (Applied Biosystems, USA) using T7 or SP6 site specific primers.

\section{Quantification of apoptosis}

$1 \times 10^{4}$ cells were seeded in 8-chamber slides (Nunc, Germany). After $24 \mathrm{~h}$, the cells were treated with $1 \mu \mathrm{g} / \mathrm{ml}$ topotecan for $48 \mathrm{~h}$. The frequency of apoptotic cells per $10^{3}$ cells was determined by light microscopical counting of hematoxylin-eosin (HE)-stained cells that showed the typical morphological hallmarks of apoptosis, i.e. chromatin condensation and/or cell fragmentation into apoptotic bodies. Counting of apoptotic cells was performed in two independent experiments and the data presented are the mean out of these experiments. Specific apoptotic death (SAD) was calculated as the frequency of apoptotic cells after exposure to topotecan minus the frequency of apoptotic cells in standard growth medium.

\section{Assessment of cell number after induction or inhibition of apoptosis}

Tumor cells in the exponential growth phase were transferred to microwell plates (Gibco, Germany) at $1 \times 10^{4}$ cells per well in $0.1 \mathrm{ml}$ standard growth medium. After $24 \mathrm{~h}$ the tumor cells were exposed to topotecan $(0.01-10 \mu \mathrm{g} / \mathrm{ml}$; kindly provided by Smith Kline Beachem, Germany) or to the CD95 receptor-activating antibody CH11 (500 ng/ $\mathrm{ml}$; Immunotech, Germany) or to recombinant human soluble (rhs) TRAIL $(100 \mathrm{ng} / \mathrm{ml})$ in combination with the recommended enhancer $(1 \mu \mathrm{g} / \mathrm{ml}$; Alexis, Germany) for another $48 \mathrm{~h}$. rhs TRAIL is a soluble form of TRAIL tagged with the FLAG epitope and used in conjunction with anti-FLAG antibodies as enhancer. Inhibitory recombinant human
TRAIL-R1-Fc and TRAIL-R2-Fc proteins (R\&D Systems, Germany) were used at $500 \mathrm{ng} / \mathrm{ml}$ in order to block induction of apoptosis by anticancer drugs. These chimeric proteins are fusion proteins of the extracellular regions of TRAIL-R1 and TRAIL-R2 with the Fc portion of human $\operatorname{lgG}_{1}{ }^{18,22,42}$ The number of viable cells was estimated using the colorimetric MTT assay described by Mosman ${ }^{55}$ and measured on a spectrophotometric plate reader (Titertek Multiskan, Germany) at $570 \mathrm{~nm}$. The percentage of viable cells in each well was calculated from the following:

$$
\text { percent viability }=\frac{\text { absorbance of test absorbance of blank }}{\text { absorbance of control absorbance of blank }}
$$

The data presented are the mean \pm SD from eight replicate wells per microtiter plate and three plates per cell line. Similar experiments were obtained in two independent experiments.

\section{Analysis of p53 mutations}

Extraction of genomic DNA was performed using the QIAmp Tissue Kit (Qiagen, Germany) according to the manufacturer's protocol. For amplification of p53 exons 5 to 8 following oligonucleotide primers were used: exons 5 and 6 : forward: $5^{\prime}$-TTCCTCTTCCTGCAGTACTC3', reverse: 5'-ATGTGCAAACC AGACCTCAG-3', exons 7 and 8: forward: 5'-GTGTTGTCTCCTAGGTTGGC-3', reverse: 5'-AAGTGAATCTGAGGC ATAAC-3'. Each amplification reaction was carried out in a total volume of $50 \mu$ l containing $200 \mathrm{ng}$ of genomic DNA $10 \mathrm{pmol}$ of reverse/forward primer, $10 \mathrm{nmol}$ dNTPs, $2 \mathrm{U}$ Taq polymerase and PCR reaction buffer (Sigma, Germany). After an initial denaturation step at $94^{\circ} \mathrm{C}$ for $2 \mathrm{~min}, 35$ cycles of denaturation at $94^{\circ} \mathrm{C}$ for $30 \mathrm{~s}$, annealing at $52^{\circ} \mathrm{C}$ for $40 \mathrm{~s}$, and extension at $72^{\circ} \mathrm{C}$ for $1 \mathrm{~min}$ as well as a last delay at $72^{\circ} \mathrm{C}$ for $10 \mathrm{~min}$. The PCR products were purified from surplus oligonucleotides using Microspin S-300 columns (Pharmacia, Germany). Sequence analysis was carried out using the forward/reverse primers as described.

\section{Statistical analysis}

Interactions between TRAIL and topotecan were analyzed by the fractional inhibition method as follows: when expressed as the fractional inhibition cell viability, additive inhibition produced by both inhibitors $(i)$ occurs when $i_{1,2}=i_{1}+i_{2}$; synergism when $i_{1,2}>i_{1}+i_{2}$; and antagonism when $i_{1,2}<i_{1}+i_{2}$. ${ }^{56}$ The concentrations of topotecan that induced a $50 \%$ reduction in cell viability $\left(\mathrm{IC}_{50}\right)$ were statistically determined by SSPS (probit analysis).

\section{Acknowledgments}

We gratefully acknowledge the excellent technical assistance of Anja Florange-Heinrichs, Martina Bellak, Heiko Stahl, and Michael Ringler. The results are part of the $\mathrm{PhD}$ thesis of Marion Déjosez and the medical thesis of Andreas Krieg. This work was supported by a grant from the Mildred Scheel-Stiftung.

\section{References}

1. Krigel RL, Padavic-Shaller KA, Rudolph AR, Konrad M, Bradley EC and Comis RL (1990) Renal cell carcinomas: treatment with recombinant interleukin-2 plus beta-interferon. J. Clin. Oncol. 8: 460-467 
2. Palmer PA, Vinke I, Evers P, Pourreau C, Oskam R, Roest G, Vlems F, Becker L, Loriaux E and Franks CR (1992) Continuous infusion of recombinant interleukin2 with or without autologous activated killer cells for the treatment of advanced renal cell carcinoma. Eur. J. Cancer. 28A: 1038-1044

3. Mickisch G, Röhrich K, Kössig J, Forster S, Tschada R and Alken P (1990) Mechanisms and modulation of multidrug-resistance in primary human renal cell carcinoma. J. Urol. 144: 755-759

4. Cordon-Cardo C, Fuks Z, Drobnjak M, Moreno C, Eisenbach L and Feldmann M (1991) Expression of HLA-A, B, C antigens on primary and metastasic tumor cell populations of human carcinomas. Cancer Res. 51: 6372-6380

5. Restifo NP, Esquivel F, Kawakami Y, Yewdell JW, Mulé JJ, Rosenberg SA and Bennink JR (1993) Identification of human cancers deficient in antigen processing. J. Exp. Med. 177: 265-272

6. Ramp U, Jaquet K, Reinecke P, Nitsch T, Gabbert HE and Gerharz CD (1997) Acquisition of TGF- $\beta 1$ resistance: An important progression factor in human renal cell carcinoma. Lab. Invest. 76: 739-749

7. Hetts SW (1998) To die or not to die. An overview of apoptosis and its role in disease. JAMA. 279: 300-307

8. Friesen C, Herr I, Krammer PH and Debatin KM (1996) Involvement of the CD95 (APO-1/Fas) receptor/ligand system in drug-induced apoptosis in leukemia cells. Nature Med. 2: 574-577

9. Friesen C, Fulda Sand Debatin KM (1997) Deficientactivation of the CD95 (APO1/ Fas) system in drug-resistant cells. Leukemia 11: 1833-1841

10. Fulda S, Sieverts H, Friesen C, Herr I and Debatin KM (1997) The CD95 (APO-1/ Fas) system mediates drug-induced apoptosis in neuroblastoma cells. Cancer Res. 57: 3823-3829

11. Müller M, Strand S, Hug H, Heinemann EM, Walczak H, Hofmann WJ, Stremmel W, Krammer PH and Galle PR (1997) Drug-induced apoptosis in hepatoma cells is mediated by the CD95 (APO-1/Fas) system and involves activation of wild-type p53. J. Clin. Invest. 99: 403-413

12. Wu GS, Bums TF, McDonald $3^{\text {rd }}$ ER, Jiang W, Meng R, Krantz ID, Kao G, Gan DD, Zhou JY, Muschel R, Hamilton SR, Spinner NB, Markowitz S, Wu G and ElDeiry WS (1997) KILLER/DR5 is a DNA damage inducible p53-regulated death receptor gene. Nat. Genet. 17: 141-143

13. Sheikh MS, Bums TF, Huang Y, Wu GS, Amundson S, Brooks KS, Fomace Jr AJ and El-Deiry WS (1998) p53-dependent and-independent regulation of the death receptor KILLER/DR5 gene expression in response to genotoxic stress and tumor necrosis factor alpha. Cancer Res. 58: 1593-1598

14. Wiley SR, Schooley K, Smolak PJ, Din WS, Huang CP, Nicholl JK, Sutherland GR, Smith TD, Rauch C and Smith CA et al (1995) Identification and characterization of a new member of the TNF family that induces apoptosis. Immunity 3: 673-682

15. Pitti RM, Marsters SA, Ruppert S, Donahue CJ, Moore A and Ashekenazi A (1996) Induction of apoptosis by Apo-2 ligand, a new member of the tumor necrosis factor cytokine family. J. Biol. Chem. 271: 12687-12690

16. Sheridan JP, Marsters SA, Pitti RM, Gumey A, Skubatch M, Baldwin D, Ramakrishnan L, Gray CL, Baker K, Wood WI, Goddard AD, Godowski P and Ashkenazi A (1997) Control of TRAIL-induced apoptosis by a family of signaling and decoy receptors. Science 277: 818-821

17. Gura T(1997) How TRAIL kills cancercells, butnotnormal cells. Science. $277: 68$

18. Walczak H, Degli-Esposti A, Johnson RS, Smolak PJ, Waugh JY, Boiani N, Timour MS, Gerhart MJ, Schooley KA, Smith CA, Goodwin RG and Rauch CT (1997) TRAIL-R2: a novel apoptosis mediating receptor for TRAIL. EMBO J. 16: 5386-5397

19. Ashkenazi A, Pai RC, Fong S, Leung S, Lawrence DA, Marsters SA, Blackie C, Chang L, McMurtrey AE, Hebert A, DeForge L, Koumenis IL, Lewis D, Harris L, Bussiere J, Koeppen H, Shahrokh Z and Schwall RH (1999) Safety and antitumor activity of recombinant soluble Apo2 ligand. J. Clin. Invest. 104: 155-162

20. Griffith TS and Lynch DH (1998) TRAIL: a molecule with multiple receptors and control mechanisms. Curr. Opin. Immunol. 10: 559-563

21. Degli-Esposti MA (1999) To die or not to die - the quest of the TRAIL receptors. J. Leuk. Biol. 65: 535-542

22. Pan G, O'Rourke K, Chinnaiyan AM, Gentz R, Ebner R, Ni J and Dixit VM (1997) The receptor for the cytotoxic ligand TRAIL. Science 276: 111-113

23. Pan G, Ni JN, Wie YF, Yu GL, Gentz R and Dixit VM (1997) An antagonist decoy receptor and a death domain-containing receptor for TRAIL. Science 277: 815818
24. Degli-Esposti MA, Smolak PJ, Walczak H, Waugh J, Haung CP, DuBose RF, Goodwin RG and Smith CA (1997) Cloning and characterization of TRAIL-R3, a novel member of the emerging TRAIL receptor family. J. Exp. Med. 186: 11651170

25. MacFarlane M, Ahmad M, Srinivasula SM, Femandes-Alnemri T, Cohen GM and Alnemri ES (1997) Identification and molecular cloning of two novel receptors for the cytotoxic ligand TRAIL. J. Biol. Chem. 272: 25417-25420

26. Mongkolsapaya J, Cowper AE, Xu XN, Morris G, McMichael AJ, Bell JI and Screaton GR (1998) Lymphocyte inhibitor of TRAIL (TNF-related apoptosisinducing ligand): a new receptor protecting lymphocytes from the death ligand TRAIL. J. Immunol. 160: 3-6

27. Degli-Esposti MA, Dougall WC, Smolak PJ, Waugh JY, Smith CA and Goodwin RG (1997) The novel receptor TRAIL-R4 induces NF-kappaB and protects against TRAIL-mediated apoptosis, yet retains an incomplete death domain. Immunity 7: 813-820

28. Marsters SA, Sheridan JP, Pitti RM, Huang A, Skubatch M, Baldwin D, Yuan J, Gurney A, Goddard AD, Godowski P and Ashkenazi A (1997) A novel receptor for Apo2L/TRAIL contains a truncated death domain. Curr. Biol. 7: 1003-1006

29. Pan G, Ni JN, Yu GL, Wie YF and Dixit VM (1998) TRUNDD, a new member of the TRAIL receptor family that antagonizes TRAIL signaling. FEBS Lett. 424: 41 - 45

30. Walczak H and Krammer PH (2000) The CD95 (APO-1/Fas) and the TRAIL apoptosis systems. Exp. Cell Res. 256: 58-66

31. Kayagaki N, Yamaguchi N, Nakayama M, Eto H, Okumura Kand Yagita H(1999) Type I interferons (IFNs) regulate tumor necrosis factor-related apoptosisinducing Ligand (TRAIL) expression on human T cells: A novel mechanism for the antitumor effects of Type 1 IFNs. J. Exp. Med. 189: 1451-1460

32. Walczak H, Miller RE, Ariail K, Gliniak B and Griffith TS (1999) Tumoricidal activity of tumor necrosis factor-related apoptosis-inducing ligand in vivo. Nat. Med. 5: $157-163$

33. Hendricks LB, Rowinsky EK, Grochow LB, Donehower RC and Kaufmann SC (1992) Effect of P-glycoprotein expression on the accumulation and cytotoxicity of topotecan (SK\&F104864), a new camptothecin analogue. Cancer Res. 52: 2268-2278

34. Screaton GR, Mongkolsapaya J, Xu XN, Cowper AE, McMichael AJ and Bell JI (1997) TRICK2, a new alternatively spliced receptor that transduces the cytotoxic signal from TRAIL. Curr. Biol. 7: 693-696

35. Arai T, Akiyama Y, Okabe S, Saito K, Iwai T and Yuasa Y (1998) Genomic organization and mutation analyses of the DR5/TRAIL receptor 2 gene in colorectal carcinomas. Cancer Lett. 133: 197-204

36. Griffith TS, Chin WA, Jackson GC, Lynch DH and Kubin MZ (1998) Intracellular regulation of TRAIL-induced apoptosis in human melanoma cells. J. Immunol. 161: $2833-2840$

37. Thomas WD and Hersey $P$ (1998) TNF-related apoptosis-inducing ligand (TRAIL) induces apoptosis in FAS ligand-resistantmelanoma cells and mediates CD4 T cell killing of target cells. J. Immunol. 161: 2195-2200

38. Kollmannsberger C, Mross K, Jakob A, Kanz L and Bokemeyer C (1999) Topotecan - A novel topoisomerase I-Inhibitor: Pharmacology and clinical experience. Oncology 56: $1-12$

39. Harris CC and Hollstein M (1993) Clinical implications of the p53 tumorsuppressor gene. New Engl. J. Med. 329: 1318-1327

40. Reiter RE, Anglard P, Liu S, Gnarra JR and Linnehan WM (1993) Chromosome 17p deletions and p53 mutations in renal cell carcinoma. Cancer Res. 53:3092 3097

41. Kastan MB, Zhan Q, EI-Deiry WS, Carrier F, Jacks T, Walsh WV, Plunkett BS, Vogelstein B and Fomace Jr AJ (1992) A mammalian cell cycle checkpoint pathway utilizing p53 and GADD45 is defective in ataxia-telangiectasia. Cell 71 $587-597$

42. Chaudhary PM, Eby M, Jasmin A, Bookwalter A, Murray J and Hood L (1997) Death receptor 5 , a new member of the TNFR family, and DR4 induce FADDdependent apoptosis and activate the NF-kappaB pathway. Immunity $7: 821$ 830

43. Schneider P, Bodmer JL, Thome M, Hofmann K, Holler N and Tschopp J (1997) Characterization of two receptors for TRAIL. FEBS Lett. 416: 329-334

44. Snell V, Clodi K, Zhao S, Goodwin R, Thomas EK, Morris SW, Kadin ME, Cabanillas F, Anreeff M and Younes A (1997) Activity of TNF-related apoptosisinducing ligand (TRAIL) in haematological malignancies. Br. J. Haematol. 99: 618-624 
45. Keane MM, Ettenberg SS, Nau MM, Russel EK and Lipkowitz S (1999) Chemotherapy augments TRAIL-induced apoptosis in breast cell lines. Cancer Res. 59: $734-741$

46. Schulze-Osthoff K, Ferrari D, Los M, Wesselborg S and Peter ME (1998) Apoptosis signaling by death receptors. Eur. J. Biochem. 254: 439-459

47. Strand S, Hofmann WJ, Hug H, Müller M, Otto G, StrandD, Mariani SM, Stremmel W, Krammer PH and Galle PR (1996) Lymphocyte apoptosis induced by CD95 (APO-1/Fas) ligand expressing tumor cells - A mechanism of immune evasion? Nature Med. 2: $1361-1366$

48. Krammer PH(1997) The tumor strikes back. New data on expression of the CD95 (APO-1/Fas) receptor/ligand system may cause paradigm changes in our view on drug treatment and tumor immunology. Cell Death Differ. 4: 362-364

49. Gliniak B and Le T (1999) Tumor necrosis factor-related apoptosis-inducing ligand's antitumor activity in vivo is enhanced by the chemotherapeutic agent CPT-11. Cancer Res. 59: 6153-6158

50. Gerharz CD, Moll R, Störkel S, Ramp U, Thoenes W and Gabbert HE (1993) Ultrastructural apperance and cytoskeletal architecture of the clear chromophilic, and chromophobe types of human renal carcinoma in vitro. Am. J. Path. 142: $851-858$
51. Gerharz CD, Moll R, Störkel S, Ramp U, Hildebrandt B, Molsberger G, Koldovsky $P$ and Gabbert HE (1995) Establishment and characterization of two divergent cell lines derived from a human chromophobe renal cell carcinoma. Am. J. Path. 146: $953-961$

52. Gerharz CD, Hildebrandt B, Moll R, Ramp U, Sarbia M, Störkel S, Koldovsky P and Gabbert HE (1996) Chromophilic renal cell carcinoma: cytomorphological and cytogenetic characterisation of four permanent cell lines. Br. J. Cancer. 74: $1605-1614$

53. Gerharz CD, Ramp U, Déjosez M, Mahotka C, Czamotta B, Bretschneider S, Lorenz I, Müller M, Krammer PH and Gabbert HE (1999) Resistance to CD95 (APO-1/Fas)-mediated apoptosis in human renal cell carcinomas: An important factor for evasion from negative growth control. Lab. Invest. 79: 1521-1534

54. Mahotka C, Wenzel M, Springer E, Gabbert HE and Gerharz CD (1999) Survivin$\triangle$ Ex3 and survivin-2B: Two novel splice variants of the apoptosis inhibitor survivin with different antiapoptotic properties. Cancer Res. 59: 6097-6102

55. Mosman T (1983) Rapid colorimetric assay for cellular growth and survival: application to proliferation and cytotoxity assays. J. Immunol. Meth. 65: 55-64

56. Webb JL (1963) Effects of more than one inhibitor. In Enzymes and Metabolic Inhibitors. (New York: Academic Press) Vol 1: pp. 487-512 